KOMÁR, Zita

\title{
FEMININE RHETORIC: \\ Feminine ANd Masculine dimensions in the context of RHetoric, Gender And Social SPHERES
}

\section{PREFACE}

In the $20^{\text {th }}$ and $21^{\text {st }}$ centuries the woman as a rhetorician and the feminine as a re-definable value in social, cultural contexts has again came into prominence: the process of modernization has brought potential for the (re)interpretation of cultural-historical frameworks, opening new paths for the discipline of rhetoric as well as the analysis of the elements of social structures, gender roles and the values of masculine - feminine dimensions.

My research in the specific field of feminine rhetoric attempts to examine the innovative notion of how women use the rhetorical elements to create alternative ways of (rhetorical) appearance and how social and gender outcomes are produced by rhetoric. In this study, I wish to analyze the appearance of rhetorical components in different political speeches by male and female orators by outlining the main components of the investigation in advance, offering the reader a fresh viewpoint.

My primary aim is to find and articulate the specific feminine and masculine traits of speechwriting and the characteristics of rhetorical argumentation through a close examination of selected texts. The study has two main parts: first a summary of the theoretical background based on rhetorical and social contexts; secondly the presentation of a research project based on a recent survey. The goal of this examination is to investigate whether feminine principles can be detected by examining the selected textual elements and if so, how we can create a rhetorical vocabulary which could serve as a background to the differentiation of feminine and masculine types of oral speeches, arguments and rhetorical skills.

In short, the core of this research is the analysis not only of visual, but also of rhetorical elements and the appearance of forms of cultural processing in rhetorical, historical and cultural frames. First of all, let me outline the key components of my paper, which will characterize Feminine Rhetoric as a discipline. I have three main foci: investigations conducted in the past, observations made in the present, and predictions about the future:

1. Female orators in the past: re-discovering female rhetoricians lost to us in history (cultural lack);

2. Female orators nowadays: re-acting by analyzing the characteristics, ways and methods of feminine rhetoric;

3. Female orators in the future: re-defining feminine values in the 21 st century.

I propose to start with the first focus, then continue with present tendencies and predictions for the future, and finally, to give shape to "revolutionary" thoughts by analyzing the possibility of outlining the emergence and implementation of an alternative style of rhetoric.

\section{PAST: Culturally lost female orators and rhetorical achievements}

Not surprisingly, for centuries the realm of rhetoric has been almost exclusively male - not because women were not practicing rhetoric, but because the tradition has never 
recognized the forms, strategies, and goals used by many women as 'rhetorical'. (Lunsford at al. 1995:6)

This principal aim focuses on building understanding, connection, and conversation with this inherited, but not fully understood or valued history of female orators within rhetoric. Andrea Lunsford (Lunsford et al. 1995:5) collected in her deeper investigations some of the features of feminine values as steps to take forward:

- listening to and for the voices of women in the history of rhetoric;

- becoming the audience who can at last give voice to women lost to us;

- examining in close detail their speech and writing;

- acknowleging and exploring the ways in which they have been using rhetoric.

In the first section of this paper I will shed light on the role of femininity in connection with rhetoric - first of all, by re-discovering the culturally lost rhetorical texts and female rhetors. This is not, however, an isolated endeavour of my own: fortunately, a number of scholars have recently turned their attention to the history of "forgotten", "dismissed" or "silenced" female rhetoricians, creating a space for a new and rich field of social science in order to provide further investigations and alternative ways of doing rhetoric.

One of the most notable works by these scholars is Andrea Lunsford's Reclaiming Rhetorica, Women in the Rhetorical Tradition (1995), in which Lunsford and her colleagues have collected a number of different texts by various authors including Aspasia, Diotima, Christine de Pisan and many others. The scope of this paper does not allow us to closely examine the work of these valuable authors, but this analysis should also open up a huge, relatively unknown space for further investigations within the realm of Rhetoric.

Reclaiming Rhetorica does not attempt to redefine a "new" rhetoric but rather to interrupt the seamless narrative usually told about the rhetorical tradition and to open up possibilities for multiple rhetorics, rhetorics that would not name and valorise one traditional, competitive, agonistic, and linear mode of rhetorical discourse but would rather incorporate other, often dangerous moves: breaking the silence; naming in personal terms; employing dialogics; recognizing and using the power of conversation; moving centripetally towards connections; and valuing indeed insisting upon - collaboration." (Lunsford at al. 1995:6).

One might ask: Why is the examination of the past so important for us in the present? Let me answer this question with an example: modern rhetoric is based in multiple ways on what we have learned of classical rhetoric, which indeed only offers us the works and thoughts of male orators and masculine types of "voicing". How then can a woman - who now has the right to step into the arena of public affairs and choose to use feminine types of rhetoric -, adopt this set of skills without any chance to "translate" the contents and structures and fit them into the context of her own language and values?

Furthermore, why should she perform this (not very successful) task of translation? As a result of our lack of information and imperfect knowledge, is she forced to speak in a more masculine manner or in other cases will she be "left outside alone" to discover her own ways of doing rhetoric? And what if she is a he: someone who wants to talk, act and think according to feminine values, at the same time retaining his position as a man? What can classical rhetorics 
offer to him? What feminine sets can classical canons of style offer to a woman, and moreover to all the women of the 21 st century, to speak up and speak loud?

At this point, the investigation of rhetoric must not come to a stop, but must rather take a step towards a new meaning of rhetorical action, persuasion and argumentation by recognizing unknown scholars and new ways of achieving rhetorical goals. Therefore, Aspasia and many other valuable female orators are becoming acknowledged members of the history of rhetoric and models for female orators and public speakers today.

I must note here that this shift towards feminine rhetorical styles does not mean that classical (or in other words, masculine) rhetoric has no place to emerge: it only means that we need to speak (and moreover to think) of different ways of doing rhetoric, admitting that there is space for both. And at the same time, both rhetor and public can profit from this fullness by giving birth to new ideas and performances, outlining a totally different world not only within the field of rhetoric but also outside it. Feminine Rhetoric's "(...) characteristic and principal aim is not deception or conquest (...) but understanding, exploration, connection, and conversation." (Lunsford at al. 1995)

\section{PRESENT \& FUTURE: collectively built feminine values and dimensions}

Now, let me move on to the examination of present symptoms and feminine values of the 20th, and indeed the 21 st centuries, according to Gerzema \& D'Antonio's recently published work:

As many pointed out to us, most of the traits exbibited by the successful entrepreneurs, leaders, organizers, and creators we profiled seemed to come from aspects of human nature that are widely regarded as feminine. (Gerzema \& D'Antonio 2013:2)

This quotation comes from the book Athena Doctrine: How Women (and the Men Who Think Like Them) Will Rule the Future, which gave an interesting insight into recent processes and changes, by contrasting feminine and masculine dimensions in public and private spheres. It seems - argues Gerzema -, that women and men are frustrated by the classical, masculine types of behaviour connected to control, competition, aggression, black and white thinking and so on that have led to many of the problems we face today - for examples: war, inequality, risk-taking mentality, scandals, etc.

As a counterpart, the authors examine what respondents think of human and also gender virtues worldwide: how they imagine the future and the ways and possibilities of change - moreover they also enquire into what can be said of the necessary and useful values of a person and of a society. Without going into details, I will cite some of the results of their investigations. Most importantly, the 64,000 respondents (selected from 13 countries around the world) said that "the world would be a better place if men thought more like women". (Gerzema - D'Antonio 2013:2)

In this worldwide investigation, respondents had to answer questions like: What does it mean to be masculine/feminine? How can we detect the so-called masculine/feminine? How can we build connections between masculine - feminine dimensions and gender categories? According to the responses:

- masculine values include: dominant, strong, arrogant, proud, ambitious, decisive, logical, aggressive, competitive, stubborn, straightforward, selfish, restrained, competent, etc. 
- neutral values include: visionary, simple, authentic, carefree, collaborative, intelligent, candid, traditional, etc.

- feminine values include: free spirited, charming, dependable, reasonable, committed, creative, flexible, intuitive, social, honest, team player, cooperative, supportive, gentle, emotional, imaginative, open, loyal, selfless, patient, encouraging, etc.

These in general correlate strongly with the feminine-masculine dimension outlined by Hofstede in his well-known research at IBM. In a nutshell, Hofstede found that there are feminine and masculine ways of organizing society structures, which are proper to each community, so we can find masculine and feminine types of cultures. (Hofstede \& Hofstede \& Minkov 1991)

According to Hofstede, masculine societies place more emphasis on the distinction between gender roles, ideals and the relationship between men and women; men also have to present a strong, dominant, sometimes harsh image, providing all the essential, material conditions for the family; men make decisions, but are not allowed to show emotions by crying, and so on. Of course, a woman is expected to do the opposite: take care of the household, raise children, and of course, obey her husband.

In contrast, feminine societies are more open to creating equality between gender roles: men and women share all the tasks around the house; both of them have the same responsibilities, such as working and earning money for the family; they can show emotions alike; weakness is not condemned socially; and quality of life is the most important of all common topics.

I have mentioned Hofstede's categories because they seem to correspond to the so-called Athenavirtues in Gerzema \& D'Antonio's book, which describes the emergence of feminine values as a global "coming up" process. How do Gerzema \& D'Antonio describe these changes? They argue that our present reality - although it still seems to be an overwhelmingly masculine world -, actually shows signs of the rule of femininity. And thanks to the characterization of recent situations, the authors can put emphasis on a powerful statement: our future (and we can already see, recognize and follow the signs of this shift) will be built upon feminine values, that can give rise to both men and women who are possessed of a predominantly feminine set of skills supporting all gender-types in the public arena or in the venues of power as well.

Finally, the authors conclude that: " $65 \%$ of people around the world believe that more female leadership in government would prompt a rise in trust and fairness and a decline in wars and scandal." (Gerzema - D'Antonio 2013:21). Results support the claim that our attitudes, norms, and expectations connected to the idea of masculinity and femininity are changing: changing enough to provide an open space for women in the public sphere and for female rhetoric in the field of public speaking.

The above discussion prompts a description of this process as the movement from a rigid, unopened image of the speaker to what Aristotle terms "ethos", a word with which he defines the true and original character of a rhetor. Nowadays the rhetor or public speaker can legitimately be a She (or a He as well - not to confuse feminine with female and masculine with male!) and could provide feminine values as identification points to rhetorical speeches. This means that there is something to search for around the house of rhetoric when we try to discover and interpret the (feminine) values of public appearance.

... a strong majority of people already recognized, at least subconsciously, the importance of feminine virtues, believing that men and women needed to meet the challenges of life with a predominantly feminine set of skills, traits, and attitudes.” (Gerzema - D'Antonio 2013:22). 
According to the Athena Doctrine's final conclusions, we can contend that feminine values are the operating system of twenty-first-century progress and that while this shift toward the feminine does not portend "the end of men," it does suggest a natural balance between the two dimensions.

\section{SURVEY RESULTS}

In the following pages, I shall outline a short summary of the results of a quantitative survey. First of all, the purpose of creating the survey was to examine people's opinions centred around public, especially political speeches. The main question was: Can we find differences between the voice of man and that of woman, and if so (as my hypothesis suggests) how can we distinguish one from the other? According to the hypothesis, on the grounds of style (appearance of argumentation structures; usage of grammatical, rhetorical elements such as metaphors; etc.) it is possible to identify feminine and masculine speech by defining classical rhetoric as Masculine and another, alternative way of doing rhetoric, the feminine way, as Feminine Rhetoric.

I chose extracts from speeches by Hungarian politicians (male and female speakers) - which were all written for particular occasions; specifically, they were designed for and delivered at celebrations of national revolutions. I chose these because I was only interested in how the respondents would try to identify the gender of the speaker, using only the given text: thus respondents would have to rely on grammatical and rhetorical elements.

To summarise the results, I would say that all the respondents expressed clear (or at least strong) images, ideas and also stereotypes about how they consider styles to be typical of female or male speakers. The respondents also made distinctions along emotional - rational dimensions (associating rational matters with male and rich emotional content with female speakers), according to well-known social stereotypes (as was reflected in one answer).

And finally, the most important part of the survey: how did people identify a masculine or feminine speaker and how did they perform in expressing their motivations, thoughts and feelings about the texts (except in a few cases, where some expressed their own uncertainty, using phrases like "this is just a feeling on my part" or "I'm really just guessing"). According to their answers, respondents detected the gender of the rhetor by referring to common "knowledge" (and gender stereotypes) and associate masculine style with male and feminine style with female orators.

These answers correlate strongly with the male and female values of the respondents in Athena Doctrine, and also with my previous categorization when I applied a coding system to the adopted elements in the texts. Here I have listed some of these metaphors and coding categories I made in advance - stressing that such actions shall include, but shall not be limited to the following phrases.

Masculine phrases: all kinds of political, economical structures and status; words like power, progress, historical progress; phrases related to motivation and national values, emphasizing achievable goals; use of paternal style and expressions, words of competition; negative feelings and impacts (for example: dividing, antipathetic or hostile expressions); etc.

Masculine style also involves the copious use of verbs and many tangible idioms, and its focus is on the future, so I characterize these as visionary types of rhetorical thinking.

By contrast, feminine phrases: refer to the family and topics which are connected with it (such as children, and different types and meanings of community); often use the word "common" in various forms; they are rich in pictorial meanings (for example, metaphors like "the horizon of our fate," "the sacred bread of the nation" etc.); often refer to collaboration, unity, compromise, solidarity, loyalty, and such notions. 
Feminine style also use many attributes and abstract phrases in rhetorical-grammatical structures (e.g. metaphors); and its focus is in the present, so I have identified this style of rhetoric as a contemplative one.

But we should not forget about the "speech-writer-problem." It can be argued that many politicians employ speech-writers to create speeches for them, and in such cases the gender of the so-called author is a misleading category, because the real author of the text is not the same person as the presenter (e.g. a female politician could have a male speech-writer). There are, however, three reasons why this should not affect our findings. First of all, politicians generally annotate their speeches, asking for corrections or other changes that will make the text better suited to their personality and ideology - it is hardly credible that any speech-writer would be able to create a definitive, final version of the text without showing a draft to the presenter in advance. Secondly, speech-writers normally suit the speech to the personality, style, ideas and beliefs of the speaker, so they are already shaping the text according to the presenter's own taste. And later on, the first draft will be discussed, as I have mentioned. Finally, my aim was not to identify the actual gender of the speaker, but to shed light on the motivations and guessing-systems of according to which the respondents make decisions about whether a speech is feminine or masculine in style.

\section{CONCLUSION}

We have now come to an end of a captivating circle: starting with the exploration of female orators of the past, then characterizing the style of present rhetorical acts, roles and social connectedness, all of which will help to promote the creation of a richer, more open and cooperative (rhetorical) tradition in the future. Now we can see the connection between the Athena-virtues, the culturally lost orators, feminine styles of acting and speaking, and the feminine style of today's speakers without having any clearly recognized rhetorical elements and techniques on the feminine side. Therefore, my last task is to draw my own conclusions.

As I have suggested, metaphors and other rhetorical components have a huge impact on identifying speech: feminine-styled speakers use a large number of powerful metaphors to express their thoughts and these metaphors are mostly connected to specific feminine values such as co-operation, community, shared emotions etc. Female rhetors use these techniques to emphasize their own commitment to a special topic - doing so in a way which is different from the classical instruments of masculine rhetoric, and also unique to the feminine voice. This could help us recognize the true character of feminine rhetoric and female orators, and also underlines the way in which a new kind of taxonomy could be built up: a vocabulary based on the so-called "feminine". Therefore, the next step will be to collect, structure and define feminine rhetoric and its vocabulary on the basis of the findings of a more comprehensive investigation.

\section{BIBLIOGRAPHY}

- Aczél, Petra 2012. Médiaretorika. Magyar Mercurius.

- Aczél, Petra 2009. Új retorika. Közélet, kommunikáció, kampány. Kalligram Könyvkiadó.

- Arisztotelész 1982. Retorika. Gondolat.

- Babbie, Earl 2008. A társadalomtudományi kutatás gyakorlata. Balassi Kiadó.

- Barát, Erzsébet - Sándor, Klára (szerk.) 2007. A nö helye a magyar nyelvhasználatban. Jatepress, Szeged.

- Bodnár, Ildikó 2008. Sokszínü nyelvészet „Női szóval - nöi szemmel”. Genderkutatás a nyelvészetben és az irodalomban. Miskolci Egyetem, Miskolc

- Carlie, L. Linda. Gender and Social Influence. Journal of Social Issues, Vol. 57, No. 4, 2001. p. 725-741. 
- Carlie, L. Linda. Gender, Language and Influence. Journal of Personality and Social Psychology 5. p. 941-951.

- Charteris-Black, Jonathan 2011. Politicians and Rhetoric. The Persuasive Power of Metaphor. Palgrave Macmillan

- Gerzema, John - D'Antonio, Michael 2013. The Athena Doctrine: How Women (and the Men Who Think Like Them) Will Rule the Future. Jossey-Bass

- Goffman, Erwing 1981. A hétköznapi élet szociálpszichológiája (Tanulmányok). Budapest, Gondolat.

- Goffman, Erwing 1969. The presentation of self in everyday life. London: Penguin Pr.,

- Hofstede, Gert - Jan, Hofstede - Michael, Minkov 1991. Cultures and Organizations: Software of the Mind, Third Edition. McGraw-Hill USA, 2010.

- Juhász, Valéria - Kegyesné, Szekeres Erika (szerk.) 2011. Társadalmi nem és nyelvhasználat 1. Válogatott szemelvények az angol és a német szakirodalomból. Szeged, Szegedi Egyetemi Kiadó.

- Koncz, Katalin 2014. Nök a politikai hatalomban. 1990-2014. Budapesti Corvinus Egyetem.

- Larner, Lindsay R. 2009. The Role of Feminine Rhetoric in Male Presidential Discourse: Achieving Speech Purpose. CUREJ - College Undergraduate Research Electronic Journal

- Lunsford, Andrea A. et al. 1995. Reclaiming Rhetorica: Women In The Rhetorical Tradition. University of Pittsburgh Press.

- Matland, R. E. - Montgomery, K. A. 2003. Women's Access to Political Power in PostCommunist Europe. Oxford University Press.

- Mazzoleni, Gianpietro 2002. Politikai Kommunikáció. Osiris.

- Retorikai Lexikon (A. Jászó Anna szerk.) 2010. Kalligram Könyvkiadó.

- Zentai, István 2004. A meggyözés útjai. A mindennapi élet meggyözéspszichológiája. Budapest: Neumann Kht.

- Zentai, István 2006. Meggyözéstechnika és kritikai gondolkodás a mindennapi gyakorlatban. Medicina Könyvkiadó Zrt. 